\section{Optimization of Learning Through Edmodo-Based Hybrid Learning to Improve Learning Independence and Learning Outcomes}

\author{
Umi Kulsum \\ Fashion Skill Program \\ State Vocational School 5 Malang, Indonesia \\ E-mail: kulsum2406@gmail.com
}

\section{http://ojs.unm.ac.id/index.php/Insani/index}

Abstract. The study aims to determine the effectiveness of the use of Edmodo as a media study review of the learning outcomes; Knowing the learning independence relationship with learning outcomes and Knowing the influence of hybrid learning on learning independence and learning outcomes. This is experimental method with NonEquivalent Control Group Design, consists of four groups of treatment with varied hybrid learning proportions, each 50\% (meaning 50\% learning hybrid learning and $50 \%$ face to face), $60 \%$ (meaning $60 \%$ of hybrid learning and $40 \%$ face to face), and $70 \%$ (meaning $70 \%$ hybrid learning and 30\% face-to-face), and one group of others is a conventional group (only face to face), this group as a control group. Data Collection with questionnaires for learning independence and knowledge tests to determine learning achievement. The results showed: (1) the use of Edmodo was effective in enhancing the results of a larger experimental class learning compared to the control class so that learning became Optimal, (2) a significant relationship of learning independence learning with learning outcomes, significance $0.000,(3)$ there is a difference of influence of significant variation of hybrid learning to learning independence and learning outcomes, with significance 0,037

Keywords: Hybrid learning, Edmodo, learning independence, learning outcomes

\section{INDONESIAN JOURNAL OF EDUCATIONAL STUDIES (IJES)}

\section{E-ISSN: 2621-6744 \\ P-ISSN: 2621-6736}

Submitted: May, $16^{\text {th }} 2020$

Accepted: May, $25^{\text {th }} 2020$

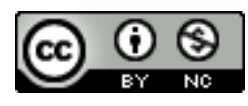

This work is licensed under a Creative Commons Attribution-NonCommercial 4.0 International License 


\section{INTRODUCTION}

The development of information and communication technology has led to a major influence on new paradigm changes in education. Along with the development of various educational devices and modern educational facilities also support the optimization of the learning process. The form of information technology that is implemented in the world of education is e-learning, where e-learning is an innovation that has a great contribution to change in the learning process. One of the changes that occur is the lack of interaction between teachers and students in the class because the available time is limited. This allows distance learning. This is supported by statements as quoted from a book entitled "Applications of CALL Theory in ESL and EFL Environments" written by Perren, et. al. (2017). In the book it is stated that e-learning. Learning can be applied. Learning by providing a concept that provides solutions in the interfere especially when students are not present in class, or lack of face-to-face time so that learning in the classroom shifts learning anywhere and anytime, physical facilities shift to a working network facility.

Department of National Education (Setiarini, Y.F., 2009:71), one of the objectives of the Fashion Skill Program is to equip students with the skills, knowledge, and attitudes to become competent in terms of choosing textile materials or fabrics. The knowledge of textiles/fabrics is essential because textiles/fabrics are the main ingredients in fashion making. Based on the data obtained from the results of the discussion with the teacher of science materials Textile subjects and observations in the classroom, it showed that in general the interest in learning textiles for students of class $X$ fashion is low, so it affects the outcomes of learning.

Students 'learning independence is required to improve learning quality and will indirectly impact the student's own quality. Lack of learning independence will an impact on students' attitudes in the learning process, including a lack of student response to the lesson; lack of interest and curiosity of students; and the lack of confidence in student ability to interpret abilities. This is demonstrated by the results of research by Chen, C. M. (2009) that the personalized e-learning system with selflearning mechanisms helps learners improve their self-learning skills. The results show that self-study: (1) Assisting learners' mechanisms by accelerating independence learning with personalized e-learning system, (2) assisting with their learning performance.

As pointed out by Shcherbina, E.Y., et. al. (2017) with topics that lead to the search for the educated paradigm that is adequate for social and economic development, and the rapid growth of the role of information technology. The purpose of this article is to increase the professionalism of teachers in the use of computer technology in education, as well as to draw the attention of the pedagogical ethnicity from e-learning to the actual form of modern Russian education practice. The research results recommend e-learning Implementation to strengthen students 'learning independence in the context of Russian education.

E-Learning has to offer learning assistance when conventional learning (classical learning) that requires a face-to-face process between teachers and students is not possible. It is supported by Tsai, A. (2011) statement that in the context 
of e-learning many theories are adopted and used in physical classroom situations, including learning in adaptive, collaborative communities, and learning scenario. Based on learning theories, electronic platforms, and a series of procedures for applying hybrid e-learning models to international accredited training courses and have been explored, developed, and evaluated. The hybrid e-Learning System provides electronic learning units, illustrations, group learning, understanding, and workshops and fulfills training from the course. The validation of this model is positive, and the results show that a hybrid e-Learning course can be applied.

Hybrid Learning is an approach that seeks to incorporate the best benefits from the "old" and "new" teaching methods so that the quality of the learning developed is the optimal quality that is better than just face-in quality or just online learning activities online. As in the article "Hybrid learning and its current role in the teaching of foreign languages" written by Klimova, B. F \& Kacetl, J. (2015). His research aims to explore the perception of hybrid learning concept hybrid and to illustrate methodologies such as face-to-face integration and online benchmarking Components. The use of innovative technologies, the conceptualization of learning paradigms, or ongoing assessment and mixed learning evaluation demonstrates the added value of its role in teaching foreign languages

Thus, it is expected to overcome problems in learning. It is supported by Essential research Atsiro, M., et.al. (2013) On the analysis of the utilization of Hybrid Learning at the University of ESA Unggul Jakarta. Conclusions that can be taken in terms of technical feasibility include: (1) hybrid learning is very helpful in the learning process; (2) technically hybrid learning meets the expected standards and procedures, making it easier to learn to teach. Allen, I. E. et.al. (2007:5) provides a clear categorization of hybrid learning, traditional learning, web enhancement, and online learning. Based on the proportions of the Comprehended online (proportion of content delivered online), It is known that a study is said to be hybrid when the $e$ learning portion is within the range of $30-79 \%$ combined with face to face learning). On the other hand, hybrid learning models encourage teachers to transform the educational paradigm of teacher-centered learning (teacher-centered learning) into student-centered learning (student-centered learning).

From some of the use of hybrid learning, the implementation of hybrid learning in this research is to use Edmodo as a learning medium. Edmodo is a social network for learning-based learning Management System (LMS). Edmodo provides facilities for teachers, students, and parents. Edmodo is a very helpful e-learning program in the learning process. Some of the benefits of Edmodo in learning, including: (1) Edmodo is highly efficient communication and discussion vehicle for teachers and students, (2) as an appropriate means for exams or quizzes, (3) teachers can provide teaching materials such as questions, photographs, doctrinal video learners to students easily and students can download the teaching materials. As stated by Toharudin, U. (2019) that Edmodo as a learning medium is more effective in improving student learning outcomes. The results showed that students who had learned to use Edmodo demonstrated a better accomplishment than that of students without using Edmodo. Therefore, it should be more creative to involve Androidbased technology as a medium and a source of science. 
Based on the exposure, researchers conducted research with the intention to know that learning with the Edmodo-based hybrid learning model could improve the learning independence of learning and outcomes of textile students Vocational High School Fashion Skill

\section{RESEARCH METHOD}

Based on the type of data, including quantitative research, the experimental method with the draft research is a Non-Equivalent Control Group Design. This design is identical to the pretest-posttest Control Group design. This Design has a control group, but it is not fully functional to control external variables that affect the implementation of the experiment. Experimental groups and control groups were chosen in consideration as well as possible with characteristics in the Foreign-each group (Thomas, J.R., et al. 2011:345). Citing the writings of Creswell, J.W. (2014:238) that this type of research is research conducted by providing certain treatment (treatment) from the research subject which is related to using experimental design pretest-posttest Control Group Design.

The study is divided into 4 (four) groups of treatments with a varied proportion of hybrid learning, each 50\% (meaning 50\% hybrid learning and 50\% face to face), $60 \%$ (meaning $60 \%$ hybrid learning and $40 \%$ face to face), and $70 \%$ (meaning $70 \%$ hybrid learning and $30 \%$ face-to-face). One other group is a conventional group, without given the treatment, this group is a control group. The samples in this study were the grade $X$ students of the fashion skill program amounting to 104 students. Data collection with a knowledge test aims to know the achievement of learning outcomes and questionnaires to know the learning independence variables. Data analysis Techniques of the establish Ancova (Covariance analysis)

\section{RESULT AND DISCUSSION}

After data analysis is conducted for hypothesis testing, the results of data analysis are conducted. Data analysis results can be seen in the following table.

Table 1. Results of analysis of experimental group 'S average study results (group 1, 2,3 ) and the control group (group 4)

\begin{tabular}{lcccc}
\hline Experiment & $\begin{array}{c}\text { The proportion of } \\
\text { Hybrid Learning } \\
\text { (\%) }\end{array}$ & Mean & $\begin{array}{c}\text { STD. } \\
\text { Deviation }\end{array}$ & $\mathbf{N}$ \\
\hline 1 & 70 & 73.46 & 8.575 & 26 \\
\hline 2 & 60 & 77.12 & 6.953 & 26 \\
\hline 3 & 50 & 69.81 & 9.108 & 26 \\
\hline 4 (Control) & 0 & 53.65 & 9.006 & 26 \\
\hline Total & & 68.51 & 12.265 & 104 \\
\hline
\end{tabular}

Dependent Variable: Learning Outcomes 
65 Indonesian Journal of Educational Studies Vol.23, No.1, June 2020

Table 2. Test results in Covariance Analysis of learning independence Learning with learning outcomes

\begin{tabular}{|c|c|c|c|c|c|c|c|c|}
\hline & $\begin{array}{l}\text { Type III Sum } \\
\text { of Squares }\end{array}$ & df & $\begin{array}{l}\text { Mean } \\
\text { Square }\end{array}$ & $\mathbf{F}$ & Sig & $\begin{array}{l}\text { Partial } \\
\text { Eta } \\
\text { Squared }\end{array}$ & $\begin{array}{l}\text { Noncent } \\
\text { Para } \\
\text { meters }\end{array}$ & $\begin{array}{l}\text { Obser } \\
\text { ved } \\
\text { Powerb }\end{array}$ \\
\hline $\begin{array}{l}\text { Corrected } \\
\text { Model }\end{array}$ & $10575.025^{a}$ & 5 & 2115.00 & 42.137 & 000 &, 683 & 210.685 & 1.000 \\
\hline Intercept & 29.540 & 1 & 9.540 & 589 & 445 &, 006 &, 589 &, 118 \\
\hline $\begin{array}{l}\text { Self- } \\
\text { reliance }\end{array}$ & 746.120 & 1 & 46.120 & 4.865 & ,000 & , 132 & 14.865 & , 968 \\
\hline Liveliness & 406.359 & 1 & 406.35 & 8.096 & ,005 &, 076 & 8.096 &, 804 \\
\hline Treatment & 440.901 & 3 & 146.359 & 2.928 &, 037 &, 082 & 8.784 &, 680 \\
\hline Error & 4918.965 & 98 & 50.194 & & & & & \\
\hline Total & 503625.000 & 104 & & & & & & \\
\hline $\begin{array}{l}\text { Corrected } \\
\text { Total }\end{array}$ & 15493.990 & 103 & & & & & & \\
\hline
\end{tabular}

a. R squared $=.683$ (Adjusted $r$ squared $=.666$ )

b. Computed using alpha $=0.05$

Table 3. Analysis Results Covariance of the difference Hybrid learning with learning outcomes

\begin{tabular}{|c|c|c|c|c|c|c|c|c|}
\hline & $\begin{array}{l}\text { Sum of } \\
\text { Squares }\end{array}$ & df & $\begin{array}{l}\text { Mean } \\
\text { Square }\end{array}$ & $\mathbf{F}$ & Sig. & $\begin{array}{l}\text { Partia } \\
\text { I Eta } \\
\text { Squ } \\
\text { ared }\end{array}$ & $\begin{array}{l}\text { Non } \\
\text { cent } \\
\text { Para } \\
\text { mete } \\
\text { rs }\end{array}$ & $\begin{array}{l}\text { Obser } \\
\text { ved } \\
\text { Powerb }\end{array}$ \\
\hline $\begin{array}{c}\text { Contras } \\
t\end{array}$ & 440.901 & 3 & 146.9 & $\begin{array}{c}2.92 \\
8\end{array}$ &, 03 &, 082 & 8.78 &, 680 \\
\hline Error & 4918.9 & $\begin{array}{l}9 \\
8\end{array}$ & 50.194 & & & & & \\
\hline
\end{tabular}

The $\mathrm{F}$ tests the effect of treatment. This test is based on the linearly independent pairwise comparisons among the estimated marginal means.

a. Computed using alpha $=0,05$ 
Table 4. Analysis results of the Covariance test Group Difference Hybrid Learning Treatment Learning outcomes

\begin{tabular}{|c|c|c|c|c|c|c|c|c|c|}
\hline \multirow{2}{*}{$\begin{array}{l}\text { Para } \\
\text { meters }\end{array}$} & \multirow{2}{*}{ B } & \multirow{2}{*}{$\begin{array}{l}\text { Std. } \\
\text { Error }\end{array}$} & \multirow{2}{*}{$\mathrm{t}$} & \multirow{2}{*}{ Sig. } & \multicolumn{2}{|c|}{$\begin{array}{l}95 \% \text { Confidence } \\
\text { Interval }\end{array}$} & \multirow{2}{*}{$\begin{array}{l}\text { Parti } \\
\text { al } \\
\text { Eta } \\
\text { Squ } \\
\text { ared }\end{array}$} & \multirow{2}{*}{$\begin{array}{l}\text { Non } \\
\text { cent } \\
\text { Para } \\
\text { meter } \\
\mathrm{s}\end{array}$} & \multirow{2}{*}{$\begin{array}{l}\text { Obser } \\
\text { ved } \\
\text { Po } \\
\text { wer }^{\text {b }}\end{array}$} \\
\hline & & & & & $\begin{array}{l}\text { Lower } \\
\text { Bound }\end{array}$ & $\begin{array}{l}\text { Upper } \\
\text { Bound }\end{array}$ & & & \\
\hline Intercept & 3.137 & 7.816 & , 401 &, 689 & -12.373 & 18.647 & ,002 & , 401 &, 068 \\
\hline $\begin{array}{l}\text { Self- } \\
\text { reliance }\end{array}$ &, 545 &, 141 & 3.85 & ,000 &, 265 &, 826 &, 132 & .855 &, 968 \\
\hline Liveliness &, 472 &, 166 & 2.84 & ,005 &, 143 &, 801 &, 076 & .845 &, 804 \\
\hline $\begin{array}{l}\text { [Treatme } \\
\mathrm{nt}=1]\end{array}$ & 3.499 & 3.203 & 1.09 &, 277 & -2.857 & 9.856 &, 012 & 1.093 &, 191 \\
\hline $\begin{array}{l}\text { [Treatme } \\
\mathrm{nt}=2]\end{array}$ & 6.406 & 3.278 & 1.95 &, 054 &,- 099 & 12.910 &, 038 & 1.954 &, 490 \\
\hline $\begin{array}{l}\text { [Treatme } \\
\mathrm{nt}=3]\end{array}$ & 6.311 & 2.464 & 2.561 & ,012 & 1.420 & 11.201 &, 063 & 2.561 &, 718 \\
\hline $\begin{array}{l}\text { [Treatme } \\
\mathrm{nt}=4]\end{array}$ & $0^{a}$ & . & . & . & . & . & - & . & · \\
\hline
\end{tabular}

The results showed that (1) the average value of learning results from the group of experimentation/treatment was greater than the control group, this suggests that the use of Edmodo is effective in learning, (2) result of the significance that is 0.000 , smaller $(<)$ than the significance 0.05 , this indicates that there is a significant relationship between learning independence with learning outcomes, (3) the significance of the results gained 0.037 , smaller $(<)$ than significance 0,05 , it denotes that there is a significant difference in the influence of hybrid learning with learning outcomes

The results of the study also showed (1) the difference of hybrid learning group first treatment with learning outcomes, significance $0.277 ;(2)$ differences hybrid learning group treatment second with learning outcomes, significance 0,054 ; (3) the difference of the hybrid learning group of third with learning outcomes, significance 0,012; (4) difference of hybrid learning. Group fourth treatment/group control with learning outcomes, significance 0,00. The results of the average analysis of the first treatment group study result 74.46 . The average outcomes of the second treatment group was 77.12. The average outcome of the third treatment group was 69.81 , the average learning result group of the fourth treatment/control group was $53-65$ 
The results of this study indicate a significant relationship between learning independence and learning outcomes. The significance value of learning independence is 0.000 , meaning that the value smaller $(<)$ than the significance of 0,05 . In addition, there is a significant difference of hybrid learning with the results of learning with significance 0.037 meaning the value is smaller $(<)$ than the significance level 0,05. From the test results conducted on all treatment groups and control groups, the highest average results gained from the study results, namely in the second treatment group with the proportion of learning hybrid $60 \%$ and conventional $40 \%$

The results of this research in accordance with the proportion of content delivered online written by Allen, I. E. et.al. (2007:5). They provide a clear category for hybrid learning, traditional learning, Web-enhanced, and online learning. Learning is said in a hybrid form when e-learning proportions are in the range of $30-79 \%$ combined with face to face learning. On the other hand, the hybrid learning model encourages teachers to transform the educational paradigm of teacher-centered learning into student-centered learning (student-centered learning).

This research is supported also by the results of the Aritonang, M. (2014) one of the more significant findings arising from his research is participation in the learning of hybrid learning presumably increase the level of motivation and confidence of the participants to learn and use English as a media instruction. Hybrid Learning participation seems very powerful to turn extrinsic motivation into intrinsic motivation to teacher participants. It is apparent that social contextual interactions in hybrid Learning triggered intrinsic motivation and the confidence of teachers. Thus, the learning approach of hybrid learning is enabled.

Some of the other studies that have been done on the hybrid learning model include Chan, E.S.K. (2010) in his plot that hybrid Learning combines information and communication technology with face-to-face learning can provide increased flexibility and variation for student interactions. In addition, hybrid learning can increase speed and efficiency inaction between teachers and students. It has been established that information and communication technologies can support student learning. As stated by Ahmad, Z \& Ismail, I.Z. (2013). The aim of his research is to determine the utilization of the learning of the hybrid in achieving the learning satisfaction of students. The research shows that hybrid learning is implemented in the era of globalization can guide administrators and educators as well as policymakers in education systems for learning activities in Indonesia. With traditional face-to-face combination methods and online learning activities online lead to the achievement factors of students ' satisfaction.

Meanwhile. Abdelrahman, N. \& Irby, Beverly J. (2016) In his article explained that hybrid Learning has been used as a method of transition learning to take advantage of face-to- front and online learning platforms. In his article the author explores how higher education sees the simultaneous use of various platforms like face-to-face, online, and hybrid platforms in teaching. The results showed that they supported online learning because it achieved more accessibility to higher education, but they believed the T-Roof learning reached a better quality of education. 
According to Ahmed, H.M.S. (2010) Hybrid e-learning Acceptance Model: learner perceptions. There are three factors to the success of the hybrid e-learning program, which are the characteristics of the instructor, the information technology infrastructure, and the organizational and technical support. The results showed that the three factors significantly and directly influenced student acceptance of the hybrid e-learning program. The infrastructure of lineups technology and organizational support has proven to be the main determinant of the instructor's characteristics as a deciding factor for the success of students ' e-learning hybrid acceptance. Support online learning as more access to higher education. Similarly, Buzzetto -More, N. A., \& Guy, R. (2006) In his study presented research findings examining the students ' perception of hybrid learning at a historically black university that operates at the University of Maryland. He was concerned that the Maryland initiative demonstrated and will result in real growth in hybrid learning. He stated that hybrid Learning is an effective and efficient development method, supporting deep knowledge analysis and enhancing student satisfaction and causing paradigm change in higher education.

As asted Tasri, L. M. (2011) In the article "Web-based Materials Development Web" That web-based teaching materials Web are material ajar that is prepared, executed, and utilized with Web media. Teaching materials are often also called Internet-based teaching materials or online teaching materials online. There are three main characteristics that are the great potential of web-based teaching materials web, namely: presenting multimedia, storing, processing, and presenting the information. Due to its online nature, web-based teaching materials web have the most prominent characteristics are hyperlink facilities. With the existence of hyperlink facilities Then the source of learning becomes that rich. Macro development of web-based teaching materials web includes measures of need analysis, design, implementation development, and evaluation.

Technological advances provide various solutions for education to create a new learning environment. Purnawarman, P., et al (2016) The purpose of his research to investigate how Edmodo as platform a learning platform, in mixed learning (hybrid) settings are implemented in the teaching of writing. The results pointed out that in teaching writing it is possible to integrate Edmodo in a combination of GBA (Genre-based Approach) and facilitate the cognitive involvement of students during classroom learning. It is supported by the research of Muhajir, et al. (20 19) indicating that the average value of the experiment class is higher than the control class. In addition, evidenced by the significance of the results of the independent sample test 0.044 . The result of such significance suggests that $0044<00.05$ or $t$ count $<$ T table then the hypothesis was accepted. It can be concluded that the application of learning media Edmodo is more effective because there are increased interest and learning outcomes.

The same research was carried out by Putri, S.R., et. al (2018) The results showed an increase in learning activity from the initial condition of $44 \%$ to $60.7 \%$ in cycle 1 and increased to $92.5 \%$ in cycle 2 . Increased learning outcomes can also be seen from the average student value of 66.7 at the initial conditions increased to 
72.37 on cycles 1 and 80.10 in cycle 2 . In conclusion, the use of Edmodo learning media can improve student activity and learning outcomes.

Zimmerman, B.J. (2008) in his article Magistrates Self-Regulation and Motivation: Historical Background, Methodological Developments, and Future Prospects. Topics about how students become self-reliant. The effort to measure (self-regulated learning) using questionnaires and interviews shows significant predictions of student learning outcomes. In his research has involved learning with the development of online measures of the process of setting up and confidence in self-motivation. This innovative method has provided valuable information about the impact of the self-learning process for future learning. Meanwhile Maher, A. (2004) Learning Outcomes in Higher Education: Implications for Curriculum Design and Student Learning. In his written article, high school master in England has undergone tremendous change in the last thirty years. The participation among students in nontraditional learning is the main challenge facing Higher Education learning outcomes can act as benchmarks to ensure quality and efficiency in colleges. Learning outcomes are used in evaluating their implications for designing curriculum and student learning.

\section{CONCLUSION}

Based on the above discussion, the research results can be concluded as follows: (1) Edmodo based hybrid learning can improve learning independence and learning outcomes; (2) there is an increase in the average value of learning outcomes in the treatment group from the control group; (3) there is a significant relationship between learning independence learning and learning outcomes; (4) there is a significant difference in the effects of hybrid learning variation on learning independence and learning outcomes; (5) learning through hybrid learning is recommended as the most effective learning trend model in optimizing the learning process, fostering students' attitudes of independence and active, creative and innovative attitudes so that it can motivate in improving and learning outcomes.

\section{REFERENCES}

Abdelrahman, N., \& Irby, B. J. (2016). Hybrid learning: Perspectives of Higher Education the Faculty. International Journal of Information Communication Technologies and Human Development (IJICTHD), 8(1), 1-25.

Ahmad, Z. \& Ismail, I.Z. (2013). Utilization of Hybrid Learning in Accomplishing Learning Satisfaction as Perceived by University Students. International Journal of e-Education, e-management, and e-learning, 3 (2)

Ahmed, H. M. S. (2010). Hybrid E-Learning acceptance model: learner perceptions. Decision Sciences Journal of Innovative Education, 8(2), 313-346.

Allen, I. E, Seamen, J. \& Garret, R. (2007). Blending in: The extent and promise of Blended Education the United States, USA: The Sloan Consortium PO Box 1238. Newburyport, MA 01950

Aritonang, M. (2014). Motivation and confidence of Indonesian teachers to use English as A medium of instruction. TEFLIN Journal, 25(2), 147-167. 
Atsiro, M., Cahyo, M., Diansyah, A., \& Hasanuddin, H. (2013). Analisis Pemanfaatan Hybrid Learning dalam Proses Belajar dan Mengajar pada Universitas Esa Unggul Jakarta. KKP Mahasiswa TI S1

Buzzetto-More, N. A., \& Guy, R. (2006). Incorporating the hybrid learning model into minority Education at a historically black University. Journal of Information Technology Education: Research, 5(1), 153-164

Chan, E.S.K. (2010) Hybrid Learning: Teaching for Quality Learning at University. Lecture Notes in Computer Science (including subseries Lecture Notes in Artificial Intelligence and Lecture Notes in Bioinformatics)

Chen, C.M. (2009). Personalized E-learning System with Self-Regulated Learning Assisted Mechanisms for Promoting Learning Performance. Expert System with Application, 36(5), 8816-8829.

Creswell, J.W. (2014). Research Design Pendekatan Kualitatif, Kuantitatif, dan Mixed. Yogyakata: Pustaka Pelajar

Klimova, B. F., \& Kacetl, J. (2015). Hybrid learning and its current role in the teaching of foreign the languages. Procedia-Social and Behavioral Sciences, 182, 477481.

Maher, A. (2004). Learning outcomes in higher education: Implications for curriculum design and student learning. Journal of Hospitality, Leisure, Sport and Tourism Education, 3 (2), 46-54. ISSN: $1473-8376$

Muhajir,M, Musfikar,R.,Hasrullah,H.(2019). Efektivitas Penggunaan e-Learning Berbasis Edmodo Terhadap Minat dan Hasil Belajar. Jurnal Pendidikan Teknologi Informasi, 3(1), 50-56

Perren, James, Kelch, Ken, Byun, Jin-Suk (2017). Applications of CALL Theory in ESL and EFL Environments, Education

Purnawarman, P., Susilowati, Sudayana, W. (2016). The Use of Edmodo in Teaching Writing in a Blended Learning Setting. Indonesian Journal of Applied Linguistics, 5(2), pp. 242-252 DOI: 10.17509/ljal. v5i 2.1348, ISSN: 25026747

Putri, S. R., Wahyuni, S., \& Suharso, P. (2018). Penggunaan media pembelajaran Edmodo untuk Meningkatkan Aktivitas dan Hasil Belajar siswa kelas $\mathrm{X}$ Pemasaran di SMK Negeri 1 Jember Tahun Ajaran 2016/2017. Jurnal Pendidikan Ekonomi: Jurnal IImiah IImu Pendidikan, Ilmu Ekonomi dan IImu Sosial, 11(2), 108-114

Setiarini, Y. F. (2009). Pembelajaran Praktikum Pada Program Keahlian Tata Busana di SMK Daerah Istimewa Yogyakarta. Jurnal Cakrawala Pendidikan,Th XXVIII, 1(1)

Shcherbina, E.Y.,et.al. (2017) Educational and Cognitive Independence of Students in E-learning. Eurasian J Anal Chem 2017;12(Interdisciplinary Perspective on Sciences 7b):1221 - 1228. DOI: https://doi.org/10.12973/ejac.2017.00247a

Tasri, L. M. (2011). Pengembangan Bahan Ajar berbasis Web.Jurnal medtek, 3(2), 1-8. Thomas, J.R. \& Nelson, J.K., Silverman, S.J. (2011). Research Methods in Physical The Activity. United States of America: Human Kinetics

Toharudin, U., Rahmiati, D., Fazriyah, N., \& Damayanti, L. F. (2019, April). Study on the Use of Edmodo in Learning Science. In the 3rd Asian Education Symposium (AES 2018). Atlantis Press. 
71 Indonesian Journal of Educational Studies Vol.23, No.1, June 2020

Tsai, A. (2011). A Hybrid e-learning model incorporating some of the principal Learning Theories. Social Behavior and Personality: An International Journal, 39(2), 145-152.

Zimmerman, B. J. (2008). Magistrates self-regulation and motivation: Historical background, Methodological Developments, and future prospects. American Educational Research Journal, 45(1), 166-183. 